\title{
キーボードのキーピッチが 操作性に及ぼす影響
}

小林 雅幸（日本西気株式会社 コーポ・ートデサ・们部）

Effect on the usability of keyboard keypitch

Masayuki Kobayashi (NEC Corporation)

1.はじめに

今回は小型化が求められている $\mathrm{A}$ 機器 の中でもキーボードの小型化について検 討した。キーボードを小型化するための 方法としてキーピッチを小さくすること を考え、キーピッチの違いが操作性に及 ほす影響を調べるために、1 $9 \mathrm{~mm}$ キーピ ッチと $18 \mathrm{~mm}$ キーピッチにしたノート型 パソコン用キーボードを試作し、入力速 度、ミス好、どちらのキーボードが使い やすいかという主観評洒について比校評 価した。

\section{2 . 実娩方法}

(1)使用器材ノート型パソコン用キーボ ード（キーボード $\mathrm{A}:$ キーピッチ $18 \mathrm{~mm}$ 、 キーボード B : キーピッチ $19.05 \mathrm{~mm}$ )、ノート型パソコン（N E C 製 $98 \mathrm{~N}$ O T E S X/E ) 、ブラインドタッチ 練習用ソフト（日本マイコン販売製チャ レンジ・ザ・ブラインドタッチ)

(2)被娩者 初級者～上級者、20４0 歳代男女 合計 12 名

(3)作業課題 ティスプレイ上に表示され る仮名文を一行づつローマ字入力する。

10 文字 $\times 10$ 行程度

(4)测定項目入力速度、ミス率、どちら のキーボードが使いやすいかの主観評価

(5)実娩手順 2 種類のキーボードを使用 してそれぞれ仮名文入力を行ない（2〜 4 分程度/種類）、どちらのキーボード が使いやすいか主観評価を行う。

\section{3. 結 果}

凶3の入力速度は被験者ことにバラッキ はあるが、キーボート間における差はな い。四 4 のミス㠰では、個々の被験者に おけるキーボード间の差はあるが、平均 値で比べるとキーボード間に差はない。 四 5 でどちらのキーボードが使いやすい かという主観評洒では、全体的にキーボ 一ドA（キーピッチ1 $8 \mathrm{~mm}$ ）を好む被験 者が多かったが、平均入力速度が速い被 験者の中にはキーボードB（キーピッチ $19 \mathrm{~mm}$ ）を好む被験者がおり、また手長 が長い被験者ではキーボードA を好む被 験者が少なかった。

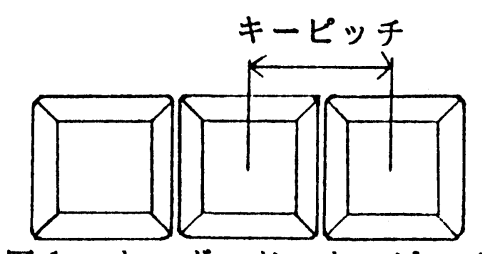

困1.キーボードのキーピッチ

おはようござます

おはようごさ 


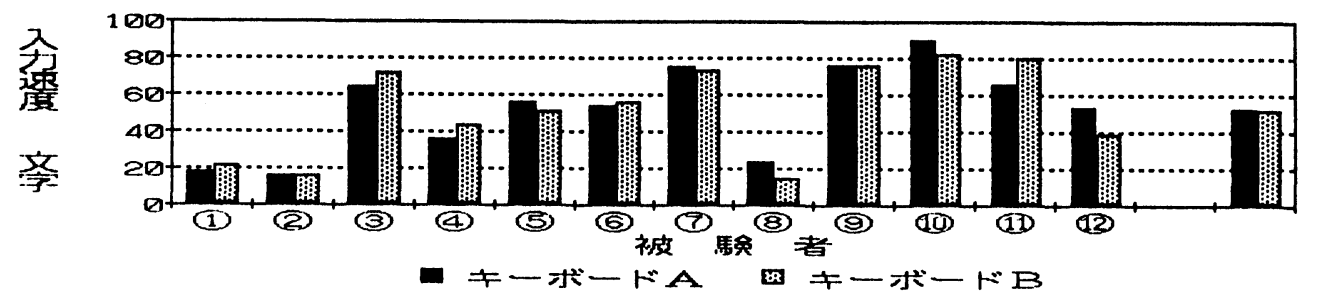

因3．被験者ごとの入力速度

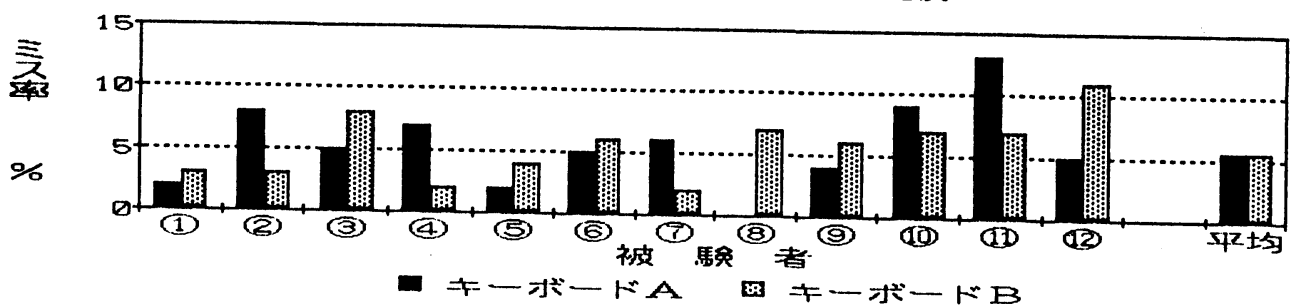

四 4。被㙑者ごとのミス率

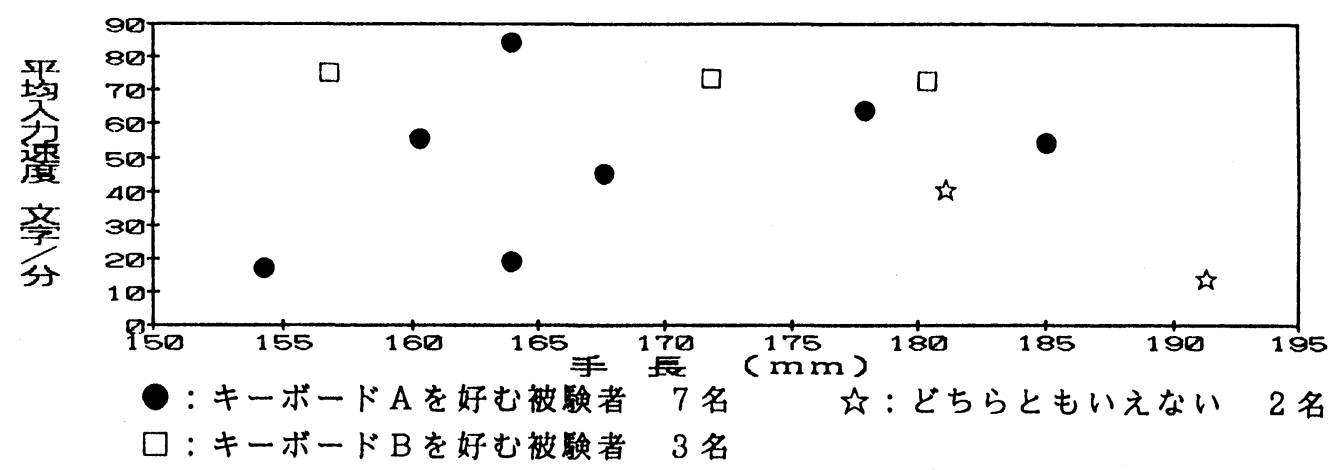

因 5。被娩者ことの主锶部洒

4.考察

入力速度については、平均值において差 がなく個々の被娩者におけるキーボード 间の差も小さいため、キーボード間に差 がないと考えられる。ミス雨については、 平均值において差がなく個々の被験者に おけるキーボード間の差はあるが、これ は実験の順序效果が影響していると思わ れ、キーボード間の差はないと考えられ る。入力速度、ミス沓ともキーボード間 における統計学的な有意差は認められな かった。主観評価については、全体的に キーボードA（キーピッチ $18 \mathrm{~mm}$ )を好 む被娩者が多く、実験後の感想の中でも キーボードAを選んだ理由として、「手 の大きさに合っている」「指がキーに届
きやすい」「指をあまり動かさないです む」などがあり、キーボード $\mathrm{A}$ を選んだ 被娩者は、キーピッチが小さい点を評価 しているのだと思われる。

5.おわりに

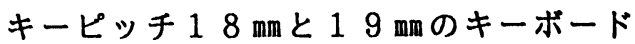
は、作業斋率においてはほとんと差がな く、どちらのキーボードが使いやすいか という主観評価においては、キーボード A（キーピッチ $18 \mathrm{~mm} ）$ を好む被唤者が 多かった。しかし入力速度の速い被験者 や手長の艮い被験者の中には、キーボー ドB（キーピッチ $19 \mathrm{~mm}$ ）を好んだり、 どちらともいえないという被娩者もいる ので、被験者の特性と主钼評価の関係を さらに检誩する必要があると思われる。 